\title{
Gender Differences In Language Classrooms In Karachi University
}

\author{
Kaleem Raza Khan \\ \& \\ Shumaila Shafket Ali \\ Department of English \\ University of Karachi
}

\begin{abstract}
Gender discrimination in every walk of society in Pakistan is one of the major issues now. The aim of this paper is to take this issue into a language classroom and to see if gender disparity is found there. To discover this, an English language proficiency classroom was selected where the academic activities of male and female learners of English were observed for ten weeks against eight variables, namely: awareness of personality, motivation for learning English, selection of topics for class discussion, style of presentation, peer evaluation, performance in classroom activities and problem solving, performance in single-gender and cross-gender groups, and test performance. The study revealed that female students were better at cognitiveacademic language proficiency whereas male learners were better at basic interpersonal communication skills. However, it was also discovered that some of the differences were culture specific rather than based on gender, i.e. there is little or no interaction between boys and girls beyond the family or school setting, hence hesitation in cross-gender communication in classrooms.
\end{abstract}

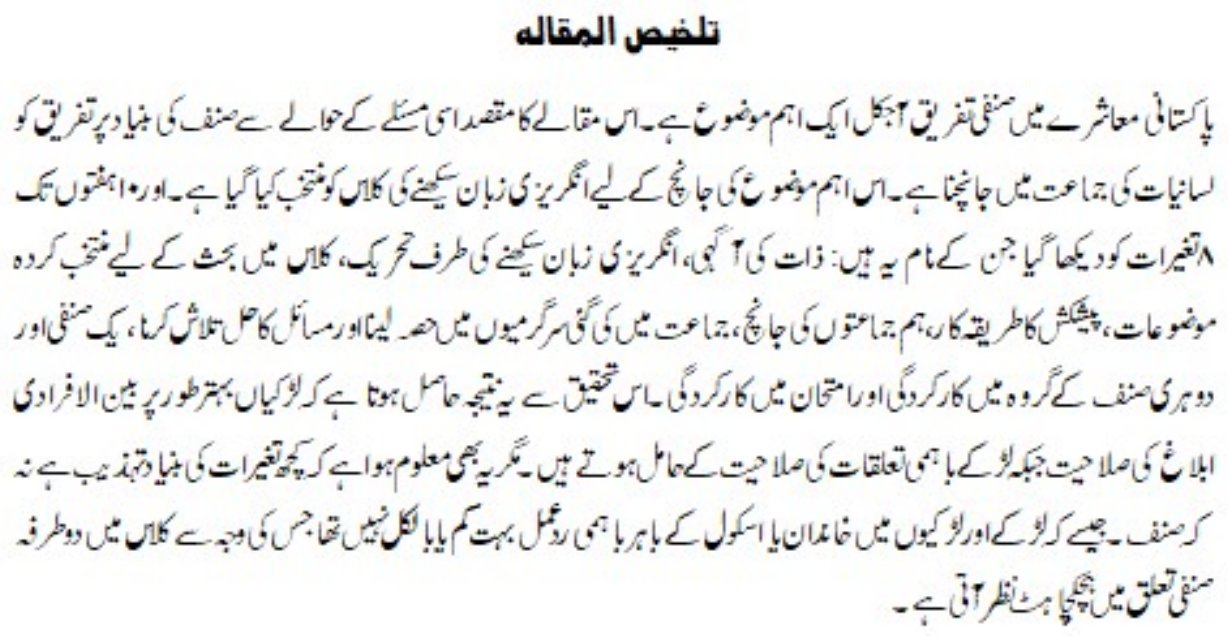

\section{Introduction}

A language classroom is a rich source of data for educational research, as learners from diverse linguistic backgrounds come together to learn the target language. The diversity in a language classroom is not only restricted to the learners' native language alone, there 
are differences in their competence in the target language, and of course, differences in terms of age, social class, and gender --- all of which have a profound effect on language learning. Since focusing on all these learner variables is beyond the scope of this study, we will confine our discussion to gender differences in classroom, the knowledge of which can contribute to our understanding of how the learners of each sex perform in class and how they perceive each others' performance.

This study is an attempt to explore gender differences that are found in language classrooms and how they effect the learning process. In order to test the validity of some research findings on language and gender, certain variables have been taken into account, for example: the kind of language used by male and female students, their reason for learning English, and the way they perform in classroom activities. The study also aims to find out if working in single gender or cross-gender group brings any change in the students' performance. Finally, it seeks to discover who progresses fast: males or females.

\section{Literature Review}

Gender has now been treated in sociolinguistics as a hot concern (Holmes and Meyerhoff 2005). Khan (1994) brought into focus the gender bias that appears to be built-in in the Urdu language that affects the language use by men and women. Sadker and Sadker (1994) focused on the complexity of gender bias in the history of American female students. Sandler, (et.al) (1996) are of the opinion that since the gender bias has always been in favour of male student from the beginning this phenomenon (gender bias) appears normal and a matter of fact, especially in the fields of science and mathematics. A collection of research papers on issues related to language and gender Caotes (2005) discussed gender differences in pronunciation and grammar, dominance in mixed conversation, gender and power, etc. Gass and Varonis (1986) discovered in their study of gender differences in classroom conversation among Japanese students of English that mixed-gender pairs had more negotiations than those of single-gender pairs. They also revealed that male learners grab more turns and they also interrupt more in classroom talk.

\section{Social and Institutional Setting}

The study is based on the data collected from the English Language Proficiency Course organized by the Students' Guidance, Counselling, and Placement Bureau at the University of Karachi. It is a ten-week course in which the classes are held three days a week from $2: 30 \mathrm{pm}$ to $4: 30 \mathrm{pm}$. The minimum eligibility criterion for getting admission in this course is an H.S.C. (Higher School Certificate). Students are divided into three groups (Elementary, Intermediate, and Advanced) according to their performance on the placement test regardless of any previous proficiency. Since the course is open to people of all age groups, not only the university students but outsiders also take admission in it. These are highly mixed groups. There are students who have just completed HSC, people who are working in government offices, lawyers, doctors, housewives, M. Phil /Ph. D. 
students. All of them have a common goal - improving English proficiency in general and speaking skills in particular.

Although the ratio of male and female students in these groups is often unequal, the elementary group under study had equal number of male and female students. The total strength of the class was 32: 16 males and 16 females. However, four students left in the middle of the course. Out of those four students, who did not continue, three were males and one female. They had different reasons for not being able to continue. The three male students, being students at another institute could not manage to complete the course because their class timings in that institute clashed with the timings of the language proficiency course. Since the course started in June, because of summer vacations, they had no problem attending the classes. But once the vacations ended, it was not possible for them to manage. The female student could not continue because of her involvement in the preparations for her sister's wedding.

\section{Discussion}

\section{Awareness of Personality}

In the very first class, in order to help students get familiar with each other, they were asked to tell three most dominant features of their personality. This activity turned out to be quite revealing in terms of the differences in personality traits between the two genders. Most of the female students described themselves to be 'friendly', 'caring', 'helpful', and 'polite', whereas the male students used terms like 'ambitious', 'adventurous', 'confident', and 'intelligent' for self-description. After sharing these traits they were asked to form eight groups of four each. Despite the fact that they were free to form cross-gender groups, the students selected members of the same sex for group formation. They were then asked to discuss with their group members the problems that they have in English. Almost all the females claimed that they lack confidence to speak in English, but hardly one or two males complained about this problem. However, most of them complained about lack of fluency and shortage of vocabulary.

\section{Motivation for Learning English}

When asked about the reason for learning English, there were obvious differences. Most of the male students want to learn English so that they can go abroad for higher studies. The male students are instrumentally motivated to learn English. Even those male students who have no such intention of leaving the country have certain instrumental reasons for learning the language; they want to learn it to get better job opportunities within the country. As far as females are concerned, although some of them, like males, want to learn English for instrumental reasons, like getting higher education and better jobs, most of them are interested in learning it to avoid suffering from inferiority complex. One of the female students, for instance, said that whenever she goes 
somewhere and sees people talking in English, she gets embarrassed because of her inability to speak it fluently. English being used as a status symbol in Pakistan, many people learn it because of their desire to be associated with the elite class, and it is observed that females are more status-conscious than males.

\section{Selection of Topics for Class Discussion}

Since the learners join this course to polish their oral communication skills, they are engaged in activities that provide them opportunities to speak. Instead of imposing any topic on them, in the first few classes they were given the freedom to select a topic of their own choice for group discussion. After discussing the topic for ten to fifteen minutes each group was asked to send one of their group representatives for presentation. It is hypothesized that females tend to talk about petty issues, while males discuss serious topics. The selection of topics by male and female groups in the English language class, however, did not manifest any such gender gap. For both groups selected serious issues for discussion. If males talked about 'cell phones', 'cable network', 'lack of electricity power' (also known as 'load-shedding' in Pakistani English). Female students discussed topics like, 'global warming', 'freedom of the press', 'internet', etc. Holmes' (1992) claim that male talk is referential (with the main purpose of conveying information), while female talk is affective (conveying interpersonal meaning) is an overgeneralization. The findings of our study indicate that the selection of the topic has more to do with the background knowledge of the learners rather than their gender. Females can also discuss topics that convey information. Such topics are not necessarily males' domain.

\section{Style of Presentation}

Although gender gap did not exist in the selection of topic, it was obvious in the style of presentation. In spite of the fact that every individual has his/her own style of presentation, there were certain stylistic features that were found to be common among all the female participants of our study. One thing that was common was the presence of long pauses. Besides this, there were unfinished sentences and lack of proper eye-contact with the audience. All of this can be attributed to lack of confidence in females. The male presenters, despite lacking fluency, appeared confident. They also gave the framework for the presentation --- something that was missing in the presentation by female students.

\section{Peer-Evaluation}

In order to discover how the students of each sex evaluate each others' performance, students were asked to write their comments at the end of each presentation. The comments of males on females' presentation and vice versa reveal interesting insight. It was found that females are more critical towards males' presentations as compared to the presentations given by their own gender, whereas males' comments for females'

presentations were quite encouraging. In the question answer session at the end of each 
presentation, however, it was observed that male students deliberately asked difficult questions from female participants to embarrass them. While describing a range of ways in which gender differentiation is maintained in classrooms, Swan (1993) observes that boys are often openly disparaging towards girls. This is true as some of the male students made fun of those female presenters who mispronounced certain words.

\section{Performance in Classroom Activities and Problem-Solving}

In order to avoid monotony and to integrate all four skills, the activities in the language proficiency course are not restricted to oral interaction alone. Students are engaged in a variety of activities, including, dialogues, role-play, problem-solving, jigsaw-reading, story completion, picture-composition, etc. Although it is hypothesized that males are better at logical and analytical activities and problem solving as compared to females, the results of the problem-solving activity proved to be just the opposite. The students were given a text along with a puzzle to solve and were given verbal instructions to avoid any misunderstanding. It was discovered that despite clear instructions, some of the male students did not understand the task and asked for reiteration of the instructions. When after re-explanation, they were given fifteen minutes to complete the task they were unable to finish it on time, whereas most of the female students solved the puzzle much earlier than the males. In another activity based on picture composition, female students outperformed males. They not only proved to be more imaginative but were also able to finish the task much earlier than the males.

\section{Performance in Single-Gender and Cross-Gender Groups}

To see how working in single-gender and cross-gender groups affects performance, the students were made to work in both types of group. For three weeks they worked in single sex group, after which they were made to work in cross-gender group for three weeks. After making them work in both types of group, they were asked as to which group they felt more comfortable working in and were also asked if they noticed any difference in their performance after working in cross-gender group. Besides this, they were also asked to decide as to which group they would prefer to work with in the remaining four weeks. The students were asked to respond to these questions in writing so that they can express their opinion more openly. With regard to the first question, only four out of sixteen female students said that they feel more comfortable working in single-sex group, the rest of them had no problem working in cross-gender group. In fact, most of the female students claimed to have become more confident after working with males and they expressed their preference to work in cross-gender group. One of the female students apart from claiming to become more confident said that males are more helpful than females and are more cooperative. Those four female students who preferred to work in single-sex group also admitted to have gained confidence while working with males. The reason for their preference for single-sex group was their friendship. Since they were all best friends, they 
wanted to be together. As far as the males are concerned, they felt comfortable in both the groups, but when they were asked to choose one, they opted for cross-gender group.

\section{Test Performance}

As pointed out in the beginning, the students are required to appear in a test which is used to assign them a level according to their current linguistic proficiency. This first test is only a placement test and once students are placed in "appropriate" groups that test loses its significance. At the end of the course all the students are examined through three different tests and they get the proficiency certificate only if they pass. There are two tests that are conducted by the class teacher: $25 \%$ Oral English, $25 \%$ Written English. Then all the students of each category (Elementary, Intermediate and Advanced) are given a $50 \%$ general proficiency objective test. It must be pointed out that the overall passing percentage is forty. Even if a student fails in one of the three tests, he/she gets the certificate if he/she scores $40 \%$ marks overall.

In order to carry out a comparative analysis, however, the students were given the same test after fifteen classes to see whether there was any difference in their progress. It was discovered that although both the genders showed progress, the female students' degree of progress was higher than the males'. There wasn't much difference in the score the male students obtained in the test before admission and the score they obtained after attending fifteen classes. The tables based on comparative analysis are presented below to show the difference in progress. Since it is against research ethics to reveal the identity of research participants, the names of students have been changed.

Result of Comparative Analysis

Table 1: Performance of Female Learners on Similar Tests

\begin{tabular}{|c|c|c|c|c|c|}
\hline Names & $\begin{array}{c}\text { Placement } \\
\text { Test: } 50\end{array}$ & $\begin{array}{l}\text { Mid-term } \\
\text { Test:50 }\end{array}$ & $\begin{array}{l}\text { End-of -the } \\
\text { term Test: } 50\end{array}$ & $\begin{array}{c}\text { Out of } \\
150\end{array}$ & $\%$ \\
\hline 1. Aasia & 05 & 15 & 29 & 49 & 32.67 \\
\hline 2. $\quad$ Alina & 11 & 20 & 26 & 57 & 38.00 \\
\hline 3. Bina & 07 & 12 & 20 & 39 & 26.00 \\
\hline 4. $\quad$ Falak * & 02 & 04 & 11 & 17 & 11.33 \\
\hline 5. Hina & 13 & 20 & 22 & 55 & 36.67 \\
\hline 6. Huma & 13 & 18 & 32 & 63 & 42.00 \\
\hline 7. Insia & 14 & 26 & 30 & 70 & 46.67 \\
\hline 8. $\quad$ Kanwal * & 10 & 12 & 20 & 42 & 28.00 \\
\hline 9. Lubna & 12 & 20 & 20 & 52 & 34.67 \\
\hline 10. Maria & 14 & 18 & 18 & 50 & 33.33 \\
\hline 11. Mehak* & 04 & 07 & 17 & 28 & 18.67 \\
\hline 12. Naila & 12 & 20 & 22 & 54 & 36.00 \\
\hline 13. Najma & 06 & 12 & 23 & 41 & 27.33 \\
\hline 14. Sadia * & 17 & 17 & 29 & 63 & 42.00 \\
\hline 15. Shazia & 16 & 22 & 28 & 66 & 44.00 \\
\hline 16. Tania & 13 & 20 & $\begin{array}{l}---- \\
\end{array}$ & $\begin{array}{l}---- \\
\end{array}$ & ----- \\
\hline
\end{tabular}


Table 2: Performance of Male Learners on Similar Tests

\begin{tabular}{|c|c|c|c|c|c|}
\hline Names & $\begin{array}{l}\text { Placement } \\
\text { Test: } 50\end{array}$ & $\begin{array}{c}\text { Mid-term } \\
\text { Test: } 50\end{array}$ & $\begin{array}{c}\text { End of the } \\
\text { term Test: } 50\end{array}$ & $\begin{array}{c}\text { Out of } \\
150\end{array}$ & $\%$ \\
\hline 1. $\quad$ Ahmed & 6 & 12 & 22 & 40 & 26.67 \\
\hline 2. $\quad$ Ashraf* & 09 & 09 & ----- & ----- & ----- \\
\hline 3. $\quad$ Bilaal & 04 & 08 & 15 & 27 & 18.00 \\
\hline 4. Hussain * & 07 & 08 & 5 & 20 & 13.33 \\
\hline 5. Irfan & 06 & 10 & 18 & 34 & 22.67 \\
\hline 6. $\quad$ Kamran * & 06 & 06 & 2 & 14 & 9.33 \\
\hline 7. Majid & 13 & 10 & 26 & 49 & 32.67 \\
\hline 8. Mushahid & 10 & 14 & 16 & 40 & 26.67 \\
\hline 9. $\quad$ Nasir * & 05 & 07 & 20 & 32 & 21.33 \\
\hline 10. Naseer & 08 & 21 & 25 & 54 & 36.00 \\
\hline 11. Riasat & 02 & 07 & 8 & 17 & 11.33 \\
\hline 12. Rizwan * & 10 & 12 & 18 & 40 & 26.67 \\
\hline 13. Sadiq & 15 & 19 & 24 & 58 & 38.67 \\
\hline 14. Tanveer * & 17 & 18 & 20 & 55 & 36.67 \\
\hline 15. Wajid & 05 & Left & ----- & ----- & ----- \\
\hline 16. Younus & 09 & Left & ----- & ----- & ----- \\
\hline
\end{tabular}

The persons marked with an asterisk $\left(^{*}\right)$ have shown no or little progress in their proficiency. There are several reasons for it:

- They were in a wrong group because some people miss the placement test and since they have paid their fee in advance the Students' Guidance, Counselling and Placement Bureau sends them to any group they choose arbitrarily.

- They usually come to the class quite late and miss the early part as a result of which they find themselves in the middle of an activity.

- They think that it is the job of the teacher to teach and not the job of the learner to learn. Therefore, they hesitate in participation. 
Final Result of Female Students

\begin{tabular}{|l|c|c|c|c|}
\hline \multicolumn{1}{|c|}{ Names } & Oral: 25 & Written: 25 & Written: 50 & Total: $\mathbf{1 0 0}$ \\
\hline 1.Aasia & 15 & 23 & 29 & 67 \\
\hline 2.Alina & 11 & 19 & 26 & 56 \\
\hline 3.Bina & 12 & 20 & 20 & 52 \\
\hline 4.Falak & 11 & 10 & 11 & 32 \\
\hline 5.Hina & 17 & 21 & 22 & 60 \\
\hline 6.Huma & 16 & 18 & 32 & 66 \\
\hline 7.Insia & 10 & 22 & 30 & 62 \\
\hline 8.Kanwal & 15 & 18 & 20 & 53 \\
\hline 9.Lubna & 15 & 17 & 20 & 52 \\
\hline 10.Maria & 10 & 12 & 18 & 40 \\
\hline 11.Mehak & 10 & 13 & 17 & 40 \\
\hline 12.Naila & 8 & 18 & 22 & 48 \\
\hline 13.Najma & 17 & 13 & 23 & 53 \\
\hline 14.Sadia & 16 & 17 & 29 & 62 \\
\hline 15.Shazia & 14 & 9 & 28 & 51 \\
\hline 16.Tania & ----- & ------ & ---- & left \\
\hline
\end{tabular}

Final Result of Male Students

\begin{tabular}{|l|c|c|c|c|}
\hline \multicolumn{1}{|c|}{ Names } & Oral: 25 & Written: 25 & Written: 50 & Total: 100 \\
\hline 1.Ahmed & 15 & 19 & 22 & 56 \\
\hline 2.Ashraf & ----- & ----- & ----- & Left \\
\hline 3.Bilaal & 15 & 10 & 15 & 40 \\
\hline 4.Hussain & A & 4 & 5 & 9 \\
\hline 5.Irfan & 20 & 22 & 18 & 60 \\
\hline 6.Kamran & 4 & 6 & 2 & 12 \\
\hline 7.Majid & 19 & 19 & 26 & 64 \\
\hline 8.Mushahid & 18 & 16 & 16 & 50 \\
\hline 9.Nasir & 10 & 15 & 20 & 45 \\
\hline 10.Naseer & 15 & 20 & 25 & 60 \\
\hline 11.Riasat & 10 & 5 & 8 & 23 \\
\hline 12.Riaz & 14 & 21 & 18 & 53 \\
\hline 13.Sadiq & 16 & 14 & 24 & 54 \\
\hline 14.Tanveer & 15 & 10 & 20 & 45 \\
\hline 15.Wajid & ------ & ------ & ----- & left \\
\hline 16.Younus & ----- & ---- & ---- & left \\
\hline
\end{tabular}

The tables clearly indicate that females progressed faster than males and this point is reinforced when one sees the final result in which all female students passed except one, 
while out of thirteen male students who appeared in the final test, three of them could not pass.

\section{General Findings}

Considering the above findings, it would not be wrong to say that males are better than females in BICS (Basic Interpersonal Communication Skills), while females are better at CALP (Cognitive Academic Language Proficiency) --- terms used by Cummins (1979). This claim can be supported on the basis of the scores the students obtained in the tests in which female students scored higher than the male students.

This does not mean, however, that males are inferior to females when it comes to learning a second language in an instructional setting. Males are better at speaking as compared to reading and writing and are ready to volunteer when asked for voluntary participation. Besides voluntary participation, male students readily participate in roleplaying and other activities that require dialogue. Females, on the other hand, show a certain degree of reluctance to participate in such activities. The reason may not be purely learning strategy, as acting is not considered a noble activity in conservative communities in Pakistan and girls who like to act in television or films are not generally judged with approval. After observing students' participation in different activities it can be inferred that performance is not always gender-specific, but most of the times it is culture-specific or activity-specific. This point can be reinforced by referring to Goodwin's (1990) ethnographic study of urban African American children in Philadelphia. On the basis of his findings, Goodwin concluded that activity-type (i.e., context) is a better predictor of speech style than gender. The differences among male and female learners are, therefore,

not entirely based on gender as they are often made out to be. To relate these differences to gender alone is an overgeneralization.

\section{References:}

Coates. Jennifer. (2005) Language and Gender: A Reader. Oxford: Blackwell.

Cummins, J. (1979) Cognitive/academic language proficiency, linguistic interdependence, the optimal age question and some other matters. Working Papers on Bilingualism. 19:197-205.

Gass, S. M. and Varonis, E. M. (1986) Sex differences in non-native speaker/non-native speaker interaction. In R.R. Day (ed.) Talking to Learn: Conversation in Second Language Acquisition. Rowley, MA: Newbury House, 327-52.

Goodwin, M. (1990) He-said-she-said: talk as social organization among black children. Bloomington. Indiana University Press. 
Holmes (1992) Women's Talk in Public Contexts. In Discourse in Society. 3 (2: 131 50)

Holmes, Janet and Meyerhoff, Miriam (eds) (2005) A Handbook of Language and Gender. Oxford: Blackwell.

Khan, Raza Kaleem. (1994) Anti-feminism in Urdu: A Study in Linguistics and Gender, in Pakistan Journal of Women's Studies Alam-e-Niswan, Vol:1, No 2, 1994, University of Karachi, pp. 65-73.

Sadker, M. \& Sadker, D. (1994) Failing at fairness: How America's schools cheat girls. New York: Charles Scribner's Sons.

Sandler, B. R., Silverberg, L. A., \& Hall, R. M. (1996) The chilly classroom climate: A guide to improve the education of women. Washington, DC: N National Association for Women in Education.

Swan, Joan. (1993) Girls, Boys and Language. Oxford: Blackwell.

Professor Kaleem Raza Khan is Chairman, Department of English, University of Karachi, Pakistan. He is currently working to complete his Ph.D. in Sociolinguistics. He has published around twenty research papers and books.

Shumaila Shafket Ali is lecturer in the department of English, University of Karachi. Besides teaching, she is also conducting research in the field of Sociolinguistics and is enrolled as an M.Phil student. Some of her articles and papers have been published in newspaper and research journals. 